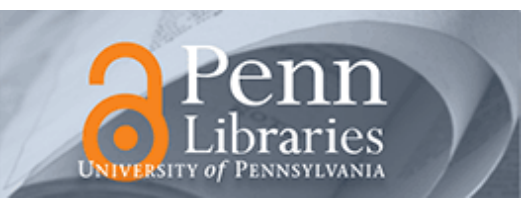

University of Pennsylvania

ScholarlyCommons

\title{
Effects of Nutrient Availability and Other Elevational Changes on Bromeliad Populations and Their Invertebrate Communities in a Humid Tropical Forest in Puerto Rico
}

\author{
Barbara A. Richardson \\ M. J. Richardson \\ Frederick Scatena \\ University of Pennsylvania, fns@sas.upenn.edu \\ William H. McDowell
}

Follow this and additional works at: https://repository.upenn.edu/ees_papers

Part of the Earth Sciences Commons, and the Environmental Sciences Commons

\section{Recommended Citation}

Richardson, B. A., Richardson, M. J., Scatena, F., \& McDowell, W. H. (2000). Effects of Nutrient Availability and Other Elevational Changes on Bromeliad Populations and Their Invertebrate Communities in a Humid Tropical Forest in Puerto Rico. Retrieved from https://repository.upenn.edu/ees_papers/44

Copyright Cambridge University Press. Reprinted from Journal of Tropical Ecology, Volume 16, Number 2, March 2000, pages 167-188.

NOTE: At the time of publication, author Fred Scatena was affiliated with the USDA Forest Service. Currently (June 2006), he is a faculty member in the Department of Earth and Environmental Science at the University of Pennsylvania.

This paper is posted at ScholarlyCommons. https://repository.upenn.edu/ees_papers/44

For more information, please contact repository@pobox.upenn.edu. 


\title{
Effects of Nutrient Availability and Other Elevational Changes on Bromeliad Populations and Their Invertebrate Communities in a Humid Tropical Forest in Puerto Rico
}

\author{
Abstract \\ Nutrient inputs into tank bromeliads were studied in relation to growth and productivity, and the \\ abundance, diversity and biomass of their animal inhabitants, in three forest types along an elevational \\ gradient. Concentrations of phosphorus, potassium and calcium in canopy-derived debris, and nitrogen \\ and phosphorus in phytotelm water, declined with increasing elevation. Dwarf forest bromeliads \\ contained the smallest amounts of debris/plant and lowest concentrations of nutrients in plant tissue. \\ Their leaf turnover rate and productivity were highest and, because of high plant density, they comprised \\ 12.8 and contained $3.3 \mathrm{t} \mathrm{ha}^{-1}$ of water. Annual nutrient budgets indicated that these microcosms were \\ nutrient-abundant and accumulated < $5 \mathrm{dwarf}$ forest, where accumulation was c. 25 biomass/plant peaked \\ in the intermediate elevation forest, and were positively correlated with the debris content/bromeliad \\ across all forest types. Animal species richness showed a significant mid-elevational peak, whereas \\ abundance was independent of species richness and debris quantities, and declined with elevation as \\ forest net primary productivity declined. The unimodal pattern of species richness was not correlated \\ with nutrient concentrations, and relationships among faunal abundance, species richness, nutrient inputs \\ and environment are too complex to warrant simple generalizations about nutrient resources and \\ diversity, even in apparently simple microhabitats.

\section{Disciplines} \\ Earth Sciences | Environmental Sciences | Physical Sciences and Mathematics

\section{Comments} \\ Copyright Cambridge University Press. Reprinted from Journal of Tropical Ecology, Volume 16, Number 2 , \\ March 2000, pages 167-188. \\ NOTE: At the time of publication, author Fred Scatena was affiliated with the USDA Forest Service. \\ Currently (June 2006), he is a faculty member in the Department of Earth and Environmental Science at \\ the University of Pennsylvania.
}




\title{
Effects of nutrient availability and other elevational changes on bromeliad populations and their invertebrate communities in a humid tropical forest in Puerto Rico
}

\author{
BARBARA A. RICHARDSON ${ }^{*} \dagger^{1}$, M. J. RICHARDSON $\dagger$, F. N. SCATENA $\ddagger$ \\ and $\mathrm{W} . \mathrm{H}$. MaDOWELL§
}

*Department of Biological Sciences, Napier University, Edinburgh EH10 5DT, UK †165 Braid Road, Edinburgh EH10 6JE, UK

$\ddagger$ International Institute of Tropical Forestry, USDA Forest Service, PO Box 25000, Rio

Piedras, Puerto Rico, 00928-2500, USA

$\S$ Department of Natural Resources, University of New Hampshire, James Hall, Durham, NH03824, USA

(Accepted 30th September 1999)

\begin{abstract}
Nutrient inputs into tank bromeliads were studied in relation to growth and productivity, and the abundance, diversity and biomass of their animal inhabitants, in three forest types along an elevational gradient. Concentrations of phosphorus, potassium and calcium in canopy-derived debris, and nitrogen and phosphorus in phytotelm water, declined with increasing elevation. Dwarf forest bromeliads contained the smallest amounts of debris/plant and lowest concentrations of nutrients in plant tissue. Their leaf turnover rate and productivity were highest and, because of high plant density, they comprised $12.8 \%$ of forest net primary productivity $\left(0.47 \mathrm{t} \mathrm{ha}^{-1} \mathrm{y}^{-1}\right)$, and contained $3.3 \mathrm{t} \mathrm{ha}^{-1}$ of water. Annual nutrient budgets indicated that these microcosms were nutrient-abundant and accumulated $<5 \%$ of most nutrients passing through them. Exceptions were $\mathrm{K}$ and $\mathbf{P}$ in the dwarf forest, where accumulation was $c .25 \%$ of inputs. Animal and bromeliad biomass/plant peaked in the intermediate elevation forest, and were positively correlated with the debris content/bromeliad across all forest types. Animal species richness showed a significant mid-elevational peak, whereas abundance was independent of species richness and debris quantities, and declined with elevation as forest net primary productivity declined. The unimodal pattern of species richness was not correlated with nutrient concentrations, and relationships among faunal abundance, species richness, nutrient inputs and environment are too complex to warrant simple generalizations about nutrient resources and diversity, even in apparently simple microhabitats.
\end{abstract}

\footnotetext{
1 To whom correspondence should be addressed, at 165 Braid Road, Edinburgh EH10 6JE, UK.
} 
KEY WORDS: abundance, biomass, bromeliads, diversity, elevation, nutrients, phytotelmata, productivity, Puerto Rico, species richness

\section{INTRODUCTION}

Resource availability, productivity and diversity have often been described as interrelated, and exhibiting a monotonic decline with increasing elevation (Begon et al. 1996, Brown \& Gibson 1983). Mounting evidence, however, suggests a peak in diversity at mid-elevational levels where nutrients and productivity are intermediate (Rosenzweig 1995). Rahbek (1995, 1997) reviewed data sets from tropical and non-tropical areas with an elevational span from below $500 \mathrm{~m}$ to above $1500 \mathrm{~m}$. He found three patterns, the 'typical' monotonic decline, a unimodal pattern and a third pattern characterized by a species richness curve that was almost horizontal up to a certain elevation before declining rapidly at high elevation. Unimodal distributions were more common than monotonic decline, and independent of region, scale and taxonomic level. While elevational trends in diversity and productivity are well documented, these relationships are often complicated by the complexity and variability of large ecosystems and, therefore, difficult to demonstrate in field experiments. Bromeliad plants, together with their total contents (canopy-derived debris, impounded water and animal communities), form microcosms whose physical, chemical and biotic parameters can be measured in their entirety (Richardson 1999). Bromeliads provide a variety of compartments and ecological gradients for their animal communities, and are true microcosms, not simple phytotelmata as regarded by some authors (e.g. Maguire 1970). We compared resource availability, bromeliad growth and productivity, and animal diversity in bromeliad microcosms in three forest types along an elevational gradient. Since gross plant morphology and location within the forest habitat remain constant along the gradient, direct comparisons of nutrient availability on animal diversity and plant productivity at different elevations can be made while the main physical features of the microcosm remain constant.

Bromeliads dominate many neotropical epiphyte communities, many species are highly specialized morphologically for the interception and utilization of non-soil nutrients (Leme \& Marigo 1993), and their animal inhabitants have attracted the attention of many biologists (Frank 1983, Laessle 1961, Picado 1913). They have been classified as anemophilous types, found in the high canopy and reliant on wind blown inorganic nutrients, and dendrophilous types, with rosettes of leaves which intercept canopy litter and leachates from foliage (Frank 1983). The latter are most abundant in the lower canopy and on the forest floor. Nutrients, released from decomposing litter in water filled tanks (phytotelmata), enter the plant via absorptive foliar trichomes (Benzing 1990). Benzing (1980) and Nadkarni \& Primack (1989) have demonstrated that foliage, rather than roots, appears to be the primary site of nutrient acquisition. Animals are major contributors to litter breakdown at all stages, from coarse 
litter collected by the rosette of leaves to the fine particulate organic matter (FPOM) which is washed into the base of the phytotelm. Thus there is transfer of nutrients to animal populations, many of which are aquatic and terrestrial larvae which, as adults, pass into the wider forest ecosystem.

Epiphytes are major interceptors of canopy litter but, because they comprise only a small fraction of the total ecosystem dry weight, they have often been overlooked in most nutrient cycling studies until those of Nadkarni (1984). Nevertheless, epiphytes contribute to nutrient cycles on death or dislodgement. Epiphytic litterfall was equivalent to 5-10\% of total fine litter biomass, and nutrient transfer via epiphytic litterfall was up to $8 \%$ of annual nutrient transfer in total fine litterfall (Nadkarni \& Matelson 1992). Lacking woody tissue, epiphytes decompose rapidly, like the foliage of their supporting trees. While these pathways of nutrient flow are widely acknowledged they have not been precisely quantified. In this paper we compare the role of these plants in nutrient cycling and their involvement in the food chains in the three forest ecosystems that exist along an elevational gradient in the Luquillo Experimental Forest.

Bromeliad density increased markedly with elevation in the Luquillo Experimental Forest (Richardson 1999), providing the largest area of bromeliads for animal colonization in the dwarf forest. The alpha diversity of animals in dendrophilous and saxicolous bromeliads declined with elevation, and reflected forest net primary productivity (NPP) when diversity measures incorporating proportional abundance (Simpson's D) were used (Richardson 1999). Species richness, however, was highest in the intermediate palo colorado forest. The marked reduction in animal diversity at the highest elevation could possibly be explained by a corresponding reduction in the amount of canopy litter intercepted by the plants. The differences in diversity between the two lower forests were not so readily explained by the amounts of litter intercepted. They may be due to differences in litter quality, particularly mineral concentrations, rather than quantity, and nutrient inputs from throughfall. We ask whether the increase in species richness at mid-elevation can be attributed to nutritional and spatial factors within the bromeliads, or to external factors such as climate and physical and plant heterogeneity of forests, which in turn determine habitat availability for animals?

\section{STUDY AREA}

The Luquillo Experimental Forest is located in the eastern, windward, portion of Puerto Rico and is the wettest part of the island. Steep elevations and the consequent changes in climate, particularly rainfall and the associated waterlogging of soils, have led to the development of different vegetation types. Four easily distinguishable forest areas are dominated by different tree species. Tabonuco (Dacryodes excelsa Vahl) forest occupies areas below $600 \mathrm{~m}$ asl, the mid-elevation palo colorado (Cyrilla racemiflora L.) forest occurs in areas above 
the cloud condensation level from 600-900 m asl, and the dwarf forest system (dominant tree Tabebuia rigida Urban), with stunted vegetation and waterlogged anoxic soils, is located only on the highest peaks above $900 \mathrm{~m}$ asl. Palm forest (Prestoea montana (R. Grah.) Nichols.) occurs at all elevations, principally on windward slopes and in wet gullies and stream valleys. Rainfall increases with elevation, with the tabonuco, palo colorado and dwarf forests receiving an annual rainfall of 3537, 4191 and $4849 \mathrm{~mm}$ respectively (García-Martinó et al. 1996). The number of rainless days decreases with elevation, such that on average the tabonuco, palo colorado and dwarf forest have 97, 69 and 53 rainless $\mathrm{d} \mathrm{y}^{-1}$ respectively. NPP is related to rainfall, and declines with elevation (Weaver \& Murphy 1990). Mean annual temperature declines from $23{ }^{\circ} \mathrm{C}$ to $19{ }^{\circ} \mathrm{C}$ over the same gradient (Weaver \& Murphy 1990).

\section{METHODS}

Sampling units were individual bromeliads, which were collected and dismantled leaf by leaf to obtain contents. Methods for collecting bromeliads, their animal communities, intercepted litter, estimating bromeliad density, and calculating species richness and diversity indices, are described by Richardson (1999). Collecting areas were in the tabonuco forest (tab) (29-405 m asl) along the Quebrada Sonadora and La Prieta rivers, palo colorado forest (pc) (750-815 $\mathrm{m}$ asl) along the Trade Winds and El Toro Trails, and dwarf forest (df) (950-980 m asl) at two areas on Pico del Este. At these elevations collecting areas were well within the boundaries of recognizable forest types. Twenty plants were collected from each of the three forest types in each of 3 y during the periods December-March 1993-1996, except that in 1996 only 10 plants were sampled from the palo colorado. To avoid pseudoreplication (Hurlbert 1984), and to ensure independence, replicates were well separated within each area, and the areas sampled were sufficiently large to give good coverage of forest type. Species sampled were facultative epiphytes with similar morphology (Guzmania berteroniana (Schult. f.) Mez, G. lingulata (L.) Mez and Vriesea sintenisii (Baker) L.B. Sm. \& Pittend.) occurring on trunks and lower branches within hands-reach, and on exposed rocks and roots. All species had small tanks and were without the large central tanks which occur in many mainland S. American species. Guzmania berteroniana occurred at all elevations, but the dominant species in the dwarf forest was $V$. sintenisii, which did not occur in the other two forests. No attempt was made to collect plants from the canopy for the main study but, in 1997, 10 plants were sampled from the tabonuco and palo colorado forests, at heights of up to $12 \mathrm{~m}$ above the ground, for comparison with 10 control plants collected near ground level, to determine whether there were any differences in animal species composition and litter interception in the lower canopy. 


\section{Bromeliad biomass and growth rate}

Leaf turnover was measured by marking 10 plants in each of the tabonuco and palo colorado forests in January 1995. A loop of tape was placed around the innermost group of leaves in the rosette, and the number of green leaves inside and outside the loop was recorded. Plants were revisited in February/ March of 1996 and 1997, and the number of new leaves counted. Ten plants were similarly marked in the dwarf forest in March 1996 and new growth recorded in February 1997. Bromeliad shoots are determinate and, after producing an inflorescence, growth continues by axillary shoots. Data on leaf production from plants which flowered during the observation period were not considered in the calculations. Bromeliad biomass was estimated by taking 11 plants (leaves and stem only) from each forest, measuring their diameter, dissecting out and thoroughly washing all green or partially green leaves and the central stem. Each plant was then oven-dried to constant weight. Good linear correlations between plant dry weight and plant diameter were obtained $\left(\mathrm{r}^{2}=0.74-\right.$ 0.84 ), and the resulting linear regression equations were used to estimate the dry weight from the diameter of the plants collected during the first $3 \mathrm{y}$ of the study. Bromeliad biomass $\mathrm{ha}^{-1}$ could therefore be estimated for each forest, using figures for plant density previously obtained (Richardson 1999).

\section{Animal biomass}

A direct measure of animal dry weight for each plant could not be obtained, because animals had to be preserved for identification. Samples of different size classes of the most frequent groups were used to estimate dry weight. Some animals collected during the study were weighed fresh and after oven-drying to constant weight. Others, previously collected into $80 \%$ ethanol, were measured, counted, and then oven-dried to constant weight. Some animals were weighed fresh but not killed, and an estimate of their dry weight was made using a factor based on the loss of weight on drying $(72.1 \% \pm \mathrm{SE}$ $1.13 \%)$. Relationships between length and mean dry weight were then estimated for the most frequently occurring species in the communities (Table 1). Estimates of weights for rarer organisms were made by interpolation on the basis of size and type categories. Dry weights of spiders were also obtained from information supplied by Dr R. E. Edwards (pers. comm.). Dry weight of animal biomass/plant was then calculated as the sum of the products of animal dry weight and number. Animals which were not considered to be bromeliad residents, e.g. larvae from the canopy, long-horn grasshoppers, frogs and large molluscs, were excluded from calculations.

\section{Chemical analysis}

The 1996 leaf and debris samples were analysed at the International Institute of Tropical Forestry laboratory with methods previously used to determine the nutrient content of other vegetation in the Luquillo Experimental Forest 
Table 1. Regression formulae and $\mathbf{r}^{2}$ values for the relationship of individual animal dry weight with length $\left(y=a x+b\right.$, where $y=$ estimated dry weight $\left(\log _{10} \mathrm{mg}\right), x=$ body length $\left(\log _{10} \mathrm{~mm}\right), a=$ regression coefficient, $\mathbf{b}=$ intercept and $\mathbf{n}=$ number of individuals measured). All coefficients are significant at $\mathrm{P}<0.001$.

\begin{tabular}{lccc}
\hline Animal group (n) & $\mathrm{a}$ & $\mathrm{b}$ & $\mathrm{r}^{2}$ \\
\hline Coleoptera larvae (463) & 2.925 & -2.78 & 0.94 \\
Coleoptera adults (575) & 2.854 & -1.61 & 0.97 \\
Diptera and Lepidoptera larvae (1507) & 2.434 & -2.57 & 0.82 \\
Blattodea (69) & 2.909 & -1.97 & 0.90 \\
Pseudoscorpiones and Scorpiones (82) & 2.280 & -1.43 & 0.98 \\
Araneae and Opiliones (21) & 2.658 & -1.16 & 0.78 \\
Chilopoda (25) & 2.616 & -2.70 & 0.82 \\
Diplopoda (62) & 2.601 & -2.08 & 0.91 \\
Isopoda (586) & 1.854 & -1.21 & 0.89 \\
All groups (4174) & 2.243 & -1.64 & 0.72 \\
\hline
\end{tabular}

(Scatena et al. 1993). Bromeliads were collected from each of the three forest types and separated into four components: live bromeliad tissue, and coarse, medium and fine debris. Samples of each component were oven-dried at $105^{\circ} \mathrm{C}$ for at least $24 \mathrm{~h}$ and ground with a Wiley mill. The ground material was analysed for phosphorus, potassium, calcium and magnesium using a Beckman plasma emission spectrometer (Spectra Span V) after a digestion in concentrated $\mathrm{HNO}_{3}$ and $30 \% \mathrm{H}_{2} \mathrm{O}_{2}$ (Luh Huang \& Schulte 1985). Nitrogen, carbon and sulphur were analysed using a LECO CNS-2000 and the dry combustion method (Tabatabai \& Bremmer 1991). Precision for all analyses was assured by running samples of known chemical composition every 40 samples.

Water samples collected in 1997 were analysed using ion chromatography, with micromembrane suppression and Dionex AS4A for anions, and CS15 for base cations. Ammonium and phosphate were analysed using flow injection colorimetry (Lachat QuikChem; indophenol blue and ammonium molybdate methods, respectively). Total dissolved $\mathrm{N}$ was measured using a high temperature Pt-catalysed combustion followed by detection as $\mathrm{NO}$ with a chemiluminescent detector (Merriam et al. 1996). Dissolved organic $\mathrm{N}$ was estimated as the difference between total dissolved $\mathrm{N}$ and the sum of ammonium and nitrate N. Dissolved organic $\mathrm{C}$ was analysed using high temperature platinumcatalysed combustion (Shimadzu TOG 5000).

\section{Annual nutrient budgets}

Budgets were estimated for bromeliads using rainfall and litter inputs from García-Martinó et al. (1996) and Weaver \& Murphy (1990). Nutrient concentrations in throughfall and litter are from McDowell (1998) and Lodge et al. (1991) respectively. Annual accumulation rates were calculated from the chemical analysis data and rates of plant turnover reported in this paper.

\section{Statistical analysis}

There was no indication that the data deviated greatly from normality, but some variances were not homogeneous and data were transformed $\left(\log _{10}\right)$ 
where necessary before analysis (Sokal \& Rohlf 1973). Biological parameters were analysed by two-way ANOVA. Multiple comparisons were made using Fisher's least significant difference (LSD) test to determine which differences between forest type or years were significant. Chemical analyses of water, debris, and plant material were carried out in one year, and were tested by one-way ANOVA. Any significant differences between forests were identified using Tukey's (equal sample size) or Scheffé's (unequal sample size) LSD tests (Groebner \& Shannon 1981).

\section{RESULTS}

\section{Bromeliad growth rate, biomass and productivity}

Dwarf forest plants were significantly smaller than those in the other two forests but their growth rate, in terms of leaf turnover, was faster, and flowering was rare (Tables 2 and 3 ). Because of their high density in the dwarf forest, their total biomass was relatively large and productivity was $12.8 \%$ of total NPP in the dwarf forest (Table 3). Palo colorado bromeliads were significantly larger than those of the other two forests, but their leaf turnover rate was lower and similar to plants in the tabonuco forest. Because of their low density, particularly in the tabonuco forest, where bromeliads are generally restricted to open riparian areas, productivity of plants in the tabonuco and palo colorado forests is less than $1 \%$ of total NPP.

Table 2. Physical parameters and biomass of bromeliads (means of three sampling periods, 1993-1996) in each of three forest types in Luquillo Experimental Forest.

\begin{tabular}{lccc}
\hline & \multicolumn{3}{c}{ Forest type $^{1}$} \\
\cline { 2 - 4 } & Tabonuco & Palo colorado & Dwarf forest \\
\hline Mean area/plant (m ${ }^{2}$ ) & $0.49^{\mathrm{a}}$ & $0.57^{\mathrm{b}}$ & $0.08^{\mathrm{c}}$ \\
Mean no. of green leaves/plant & $36^{\mathrm{a}}$ & $29^{\mathrm{b}}$ & $22^{\mathrm{c}}$ \\
Mean no. of dead leaves/plant & $8^{\mathrm{a}}$ & $6^{\mathrm{b}}$ & $19^{\mathrm{c}}$ \\
Water (ml/plant) & $166^{\mathrm{a}}$ & $134^{\mathrm{a}}$ & $103^{\mathrm{b}}$ \\
Water (t ha ${ }^{-1}$ ) & 0.007 & 0.41 & 3.3 \\
Plant density (ha ${ }^{-1}$ ) & 45 & 3100 & 32000 \\
Bromeliad mean dry wt/plant (g) & $27.1^{\mathrm{a}}$ & $35.5^{\mathrm{b}}$ & $17.2^{\mathrm{c}}$ \\
Coarse litter (g D.W./plant) & $13.7^{\mathrm{a}}$ & $20.8^{\mathrm{b}}$ & $2.7^{\mathrm{c}}$ \\
Medium litter (g. D.W./plant) & $7.0^{\mathrm{a}}$ & $8.8^{\mathrm{b}}$ & $0.7^{\mathrm{c}}$ \\
Fine (< l.5 mm) litter (g. D.W./plant) & $7.5^{\mathrm{a}}$ & $9.7^{\mathrm{b}}$ & $1.2^{\mathrm{c}}$ \\
Total litter (g D.W./plant) & $28.1^{\mathrm{a}}$ & $39.3^{\mathrm{b}}$ & $4.6^{\mathrm{c}}$ \\
Bromeliad plant dry wt (kg ha $\left.{ }^{-1}\right)$ & 1.2 & 111 & 550 \\
Total plant and debris dry wt (kg ha ${ }^{-1}$ ) & 2.5 & 233 & 696 \\
\hline
\end{tabular}

1. Values in any row with a different superscripted letter significantly different (Fisher's LSD test, $\mathrm{P}<$ $0.05)$.

\section{Animal biomass, abundance and species richness}

The regression relationships obtained for dry weight on length for the various groups of animals were highly significant $(P<0.001$, Table 1$)$. The dry weight of animals per plant was positively and significantly correlated $\left(\mathrm{r}^{2}=\right.$ 
Table 3. Phenological, growth and productivity estimates for bromeliads (mean \pm SE ( $n$ of plants)) for three sampling periods (1993-1996) in each of three forest types in Luquillo Experimental Forest.

\begin{tabular}{lccc}
\hline & \multicolumn{3}{c}{ Forest type $^{1}$} \\
\cline { 2 - 4 } & Tabonuco & Palo colorado & Dwarf forest \\
\hline No. of green leaves at start & $26.4 \pm 1.46(16)$ & $18.3 \pm 0.59(20)$ & $18.3 \pm 0.97(9)$ \\
New leaves produced $\mathrm{y}^{-1}$ & $11.0 \pm 2.27(5)$ & $7.7 \pm 0.63(15)$ & $20.6 \pm 1.38(9)$ \\
Plants flowered (\%) & 60 & 22 & 0 \\
Leaves lost $\mathrm{y}^{-1}$ & $12.9 \pm 1.78(16)$ & $7.1 \pm 0.52(19)$ & $15.7 \pm 0.77(9)$ \\
Time for innermost leaf at start to be lost (y) & $2.85 \pm 0.46(16)$ & $2.86 \pm 0.48(19)$ & $1.16 \pm 0.01(9)$ \\
Bromeliad productivity $\left(\mathrm{kg} \mathrm{ha}^{-1} \mathrm{y}^{-1}\right)$ & 0.42 & 38.8 & 474.1 \\
Forest productivity $\left(\mathrm{t} \mathrm{ha}^{-1} \mathrm{y}^{-1}\right)^{2}$ & 10.5 & 7.6 & 3.7 \\
\% forest NPP & 0.004 & 0.51 & 12.8 \\
\hline
\end{tabular}

1. One dwarf forest plant was missing after year 1; one palo colorado and two tabonuco plants were missing at the end of year 2, and two had broken tapes, so could not provide second year data. Plants which had clearly flowered a long time previously were not used in calculation of leaf production data, since their growth had been diverted to new shoot production.

2. From Weaver \& Murphy (1990).

$0.71, \mathrm{P}<0.001$ ) with the debris content of the bromeliads (Table 4). Both were significantly lower in the dwarf forest than in the other two forests, and highest in the palo colorado. In all cases the proportion of animal biomass to total debris in the plants was less than $0.5 \%$ (Table 4 ).

Animal abundance decreased with increasing elevation. Although the differences in abundance between the tabonuco and palo colorado forests were not significant, consistently fewer individuals were present in palo colorado bromeliads in all $3 \mathrm{y}$ of study. Abundance was significantly lower in the dwarf forest and animals were smaller (Table 4). The additional data from 1996 confirmed the observation (Richardson 1999) that species richness was highest in the palo colorado, the Margalef species richness indices for the three forest types being 10.5 (tab), 13.9 (pc) and 7.0 (df), respectively. Two-way ANOVA of these indices over the 3 y for three forest types showed no significant difference between years $(P=0.35)$, but highly significant differences between forest types $(P=$ 0.009). The total number of species over 3 y were 167, 198 and 97 in the three forest types, respectively. Mean invertebrate size followed the same pattern as bromeliad plant size, being largest in the intermediate palo colorado forest and smallest in the dwarf forest (Table 4).

There were no significant differences, in animal abundance or amount of litter intercepted, between plants from the lower canopy, and those collected from trunks and the ground in 1997. Significantly more debris accumulated in palo colorado than in tabonuco plants, consistent with results from previous years (Table 4). No different species assemblages were found in plants collected from higher in the trees within the same forest, but there were some significant differences in species distribution. Cased chironomid (Tanytarsini) and elaterid (Platycrepidius sp.) larvae were more frequent in the high level plants and scirtid beetle larvae were more frequent in the low level plants. Spiders in the lower canopy plants were all those species normally found in canopy sampling, and species characteristic of forest floor communities were 
Table 4. Estimates of mean animal abundance, size and biomass in bromeliads, relative to debris quantities, for three sampling periods (1993-1996) in each of three forest types in Luquillo Experimental Forest.

\begin{tabular}{lccc}
\hline & \multicolumn{3}{c}{ Forest type $^{1}$} \\
\cline { 2 - 4 } & Tabonuco & Palo colorado & Dwarf forest \\
\hline Mean no. of organisms plant & $166^{\mathrm{a}}$ & $141^{\mathrm{a}}$ & $58^{\mathrm{b}}$ \\
Mean animal biomass dry wt/plant (mg) & $75^{\mathrm{a}}$ & $113^{\mathrm{b}}$ & $15^{\mathrm{c}}$ \\
Total bromeliad debris dry wt/plant (g) & $28.1^{\mathrm{a}}$ & $39.3^{\mathrm{b}}$ & $4.6^{\mathrm{c}}$ \\
Mean animal biomass dry wt (g ha ${ }^{-1}$ ) & 3.4 & 350 & 480 \\
Total bromeliad debris (kg ha ${ }^{-1}$ ) & 1.3 & 122 & 146 \\
Animal biomass as \% of bromeliad debris & 0.26 & 0.29 & 0.33 \\
Animal size index (number of individuals g $^{-1}$ D.W.) & 2197 & 1248 & 3867 \\
\hline
\end{tabular}

1. Values in any row with a different superscripted letter significantly different (Fisher's LSD test, P < 0.05).

absent (Dr R. E. Edwards, pers. comm.). Forest floor litter dwellers, however, such as isopods, diplopods and chilopods were all well represented in the lower canopy plants in the palo colorado, but were infrequent or absent from those from the tabonuco forest.

\section{Nutrient concentrations}

In the tabonuco forest, nutrient concentrations in bromeliad debris were similar to those found in litter from the forest floor (Table 5). Tabonuco debris contained significantly higher concentrations of $\mathrm{P}, \mathrm{K}$ and $\mathrm{Ca}$ than palo colorado debris (Table 5). Concentrations of $\mathrm{P}$ and $\mathrm{Ca}$ in palo colorado debris were higher than in the dwarf forest, but differences were not significant. Iron and aluminium accumulated during the decay process in all forest types, and were at their highest levels in the fine debris of the dwarf forest.

Potassium and magnesium occurred at higher concentrations in bromeliad foliage in the tabonuco forest than in leaves of the dominant tree, while $\mathrm{Ca}, \mathrm{P}$ and $\mathrm{N}$ were lower (Table 5 ). At $2.5 \%$ dry weight, $\mathrm{K}$ was more concentrated in these epiphytes than is typical (1.5\%) for foliage of trees native to lowland moist tropical forests on moderately fertile soils (Vitousek \& Sanford 1986). Bromeliads in the dwarf forest had significantly lower tissue concentrations of $\mathrm{P}, \mathrm{K}, \mathrm{Ca}$ and $\mathrm{Mg}$, but not $\mathrm{N}(0.72-0.75 \%$ in all forests) than those in other forests. Dwarf forest bromeliads had higher levels of $\mathrm{K}$ than the dominant tree (Table 5). For comparison, nutrient concentrations in Luquillo Experimental Forest bromeliads are shown for those with total epiphytes (including nonvascular plants) in other forests (Figure 1). They are in the higher range for $\mathrm{K}$ and $\mathrm{Mg}$ but among the lowest for $\mathrm{P}$ and $\mathrm{Ca}$ and within the median values for N (Benzing 1990, Hofstede et al. 1993).

Nutrient concentrations in impounded water in the tabonuco bromeliads were significantly higher for TDN, $\mathrm{NH}_{4}, \mathrm{DON}, \mathrm{DOC}$ and $\mathrm{P}$ than in the other two forests, and lowest in the dwarf forest. Compared to rainfall and throughfall from the tabonuco forest, bromeliad water had higher concentrations of all nutrients (Table 6). Comparative data for the other two forests are not available, but are not thought likely to be greatly different, though dwarf 
Table 5. Nutrient concentrations (dry weight) of bromeliad plant tissue, debris within plants, bromeliad invertebrates and representative canopy dominants according to forest type in the Luquillo Experimental Forest ( $\mathrm{n}=$ number of samples).

\begin{tabular}{|c|c|c|c|c|c|c|c|c|c|c|c|c|}
\hline & \multicolumn{11}{|c|}{ Concentration $^{1}$} \\
\hline & & $\mathbf{n}$ & $\mathrm{C}$ & $\mathbf{N}$ & $\mathrm{S}$ & $\mathbf{P}$ & & $\mathrm{Ca}$ & $\mathrm{Mg}$ & $\mathrm{Fe}$ & Mn & $\mathrm{Al}$ \\
\hline \multicolumn{13}{|l|}{ Plant } \\
\hline & Tab & 4 & $47.76^{\mathrm{a}}$ & 0.72 & 0.24 & $0.48^{\mathrm{a}}$ & $25.51^{\mathrm{a}}$ & $1.88^{\mathrm{a}}$ & $2.16^{\mathrm{a}}$ & $0.04^{\mathrm{a}}$ & $0.09^{\mathrm{a}}$ & 0.14 \\
\hline & $\mathrm{PG}$ & 3 & $47.39^{\mathrm{a}}$ & 0.75 & 0.26 & $0.35^{\mathrm{b}}$ & $27.25^{\mathrm{a}}$ & $1.80^{\mathrm{a}}$ & $2.41^{\mathrm{a}}$ & $0.06^{b}$ & $0.25^{\mathrm{b}}$ & 0.07 \\
\hline & $\mathrm{DF}$ & 3 & $50.39^{\mathrm{b}}$ & 0.75 & 0.22 & $0.19^{c}$ & $15.56^{\mathrm{b}}$ & $0.71^{\mathrm{b}}$ & $1.01^{\mathrm{b}}$ & $0.01^{\mathrm{c}}$ & $0.08^{c}$ & 0.06 \\
\hline \multicolumn{13}{|l|}{ Coarse debris } \\
\hline & Tab & 4 & $52.01^{\mathrm{a}}$ & 1.40 & $0.40^{\mathrm{a}}$ & $0.24^{a}$ & $1.86^{\mathrm{a}}$ & $9.77^{\mathrm{a}}$ & $1.95^{\mathrm{a}}$ & $0.21^{\mathrm{a}}$ & $0.40^{\mathrm{a}}$ & 1.80 \\
\hline & PG & 3 & $60.23^{b}$ & 1.16 & $0.27^{\mathrm{b}}$ & $0.18^{\mathrm{ab}}$ & $1.07^{\mathrm{bc}}$ & $5.68^{b}$ & $1.00^{\mathrm{b}}$ & $0.24^{\mathrm{a}}$ & $0.47^{\mathrm{a}}$ & 0.87 \\
\hline & $\mathrm{DF}$ & 3 & $54.81^{\mathrm{a}}$ & 1.24 & $0.36^{\mathrm{a}}$ & $0.14^{\mathrm{b}}$ & $0.73^{\mathrm{c}}$ & $4.11^{\mathrm{b}}$ & $1.30^{\mathrm{a}}$ & $0.51^{\mathrm{b}}$ & $0.04^{b}$ & 0.71 \\
\hline \multicolumn{13}{|l|}{ Medium debris } \\
\hline & Tab & 5 & 53.04 & 2.06 & 0.62 & $0.54^{\mathrm{a}}$ & $1.07^{\mathrm{a}}$ & $7.79^{\mathrm{a}}$ & 1.15 & $1.66^{\mathrm{ab}}$ & $0.27^{\mathrm{a}}$ & 3.66 \\
\hline & $\mathrm{PG}$ & 6 & 53.73 & 1.81 & 0.55 & $0.27^{\mathrm{b}}$ & $0.66^{\mathrm{b}}$ & $4.69^{\mathrm{ab}}$ & 0.95 & $1.00^{\mathrm{a}}$ & $0.40^{\mathrm{a}}$ & 1.93 \\
\hline & $\mathrm{DF}$ & 4 & 51.25 & 1.39 & 0.52 & $0.19^{c}$ & $0.81^{\mathrm{a}}$ & $2.99^{b}$ & 1.24 & $2.17^{\mathrm{b}}$ & $0.03^{b}$ & 2.99 \\
\hline \multicolumn{13}{|l|}{ Fine debris } \\
\hline & Tab & 5 & $50.38^{a}$ & $2.31^{\mathrm{a}}$ & $0.81^{\mathrm{a}}$ & $0.77^{\mathrm{a}}$ & $1.10^{\mathrm{a}}$ & $8.02^{\mathrm{a}}$ & $1.37^{\mathrm{a}}$ & $2.53^{\mathrm{a}}$ & $0.20^{\mathrm{a}}$ & $5.60^{\mathrm{a}}$ \\
\hline & $\mathrm{PG}$ & 3 & $50.71^{\mathrm{a}}$ & $1.65^{b}$ & $0.72^{\mathrm{b}}$ & $0.38^{\mathrm{b}}$ & $0.93^{\mathrm{a}}$ & $4.60^{\mathrm{b}}$ & $1.40^{\mathrm{a}}$ & $2.49^{a}$ & $0.25^{\mathrm{a}}$ & $5.10^{\mathrm{a}}$ \\
\hline & $\mathrm{DF}$ & 4 & $43.81^{\mathrm{b}}$ & $1.87^{\mathrm{ab}}$ & $0.58^{\mathrm{c}}$ & $0.30^{\mathrm{b}}$ & $1.70^{\mathrm{b}}$ & $5.24^{\mathrm{ab}}$ & $2.51^{\mathrm{b}}$ & $4.96^{b}$ & $0.06^{\mathrm{b}}$ & $9.47^{\mathrm{b}}$ \\
\hline \multicolumn{13}{|c|}{ To } \\
\hline & Tab & 18 & 51.83 & 1.81 & 0.57 & 0.45 & 1.46 & 8.81 & 1.60 & 1.19 & 0.31 & 3.27 \\
\hline & PG & 13 & 56.09 & 1.45 & 0.46 & 0.25 & 0.93 & 5.15 & 1.09 & 1.03 & 0.39 & 2.26 \\
\hline & $\mathrm{DF}$ & 13 & 51.01 & 1.45 & 0.46 & 0.20 & 1.01 & 4.13 & 1.60 & 2.10 & 0.04 & 3.60 \\
\hline \multicolumn{2}{|l|}{ Invertebrates } & 2 & 50.0 & 12.1 & 0.64 & 13.8 & 28.7 & 40.0 & 4.09 & & & \\
\hline \multicolumn{2}{|c|}{ Tabonuco litter ${ }^{3}$} & & & 1.39 & & 0.45 & 1.05 & 6.2 & 1.3 & & & \\
\hline \multicolumn{13}{|l|}{ Leaves of } \\
\hline \multicolumn{3}{|c|}{ Dacryodes excelsa ${ }^{4}$} & & 1.33 & & 0.63 & 5.44 & 4.54 & 1.17 & & & \\
\hline \multicolumn{2}{|c|}{ Cyrilla racemiflora ${ }^{5}$} & & & 0.69 & & 0.66 & 9.34 & 1.65 & 0.69 & & & \\
\hline \multicolumn{2}{|c|}{ Tabebuia rigida ${ }^{5}$} & & & 1.15 & & 0.67 & 8.74 & 2.92 & 3.09 & & & \\
\hline \multicolumn{2}{|c|}{ Tabebuia rigida ${ }^{6}$} & & & 0.99 & & 0.6 & 5.1 & & & & & \\
\hline
\end{tabular}

1. Values in each column, for plant and each debris component, with a different superscripted letter significantly different (Scheffé's LSD test, $\mathrm{P}<0.05$ ).

2. 'All debris' is the overall mean for the three components combined, weighted by the proportion of each.

3. Silver (1992).

4. Scatena et al. (1993).

5. Sánchez, López \& Lugo (1997).

6. Medina, Cuevas \& Weaver (1981).

forest leaves are sclerophyllous and, therefore, less vulnerable to leaching (Asbury et al. 1994). The high concentrations of $\mathrm{DOC}$ and $\mathrm{NH}_{4}$, and the low concentration of $\mathrm{NO}_{3}$, suggest a tendency to anoxia in phytotelmata, decreasing from tabonuco to dwarf forest.

\section{Bromeliad biomass and nutrient storage by forest type}

The biomass of live bromeliads, and live bromeliads plus contents (debris, water and invertebrates) per unit area, increases from the tabonuco to the dwarf forest because of increasing plant density. As a consequence, nutrient storage increases with elevation (Table 7). The total bromeliad biomass, however, in Luquillo Experimental Forest forest types (with a maximum of $0.55 \mathrm{t}$ $\mathrm{ha}^{-1}$ in the dwarf forest, Table 2) is low compared with that reported for total 


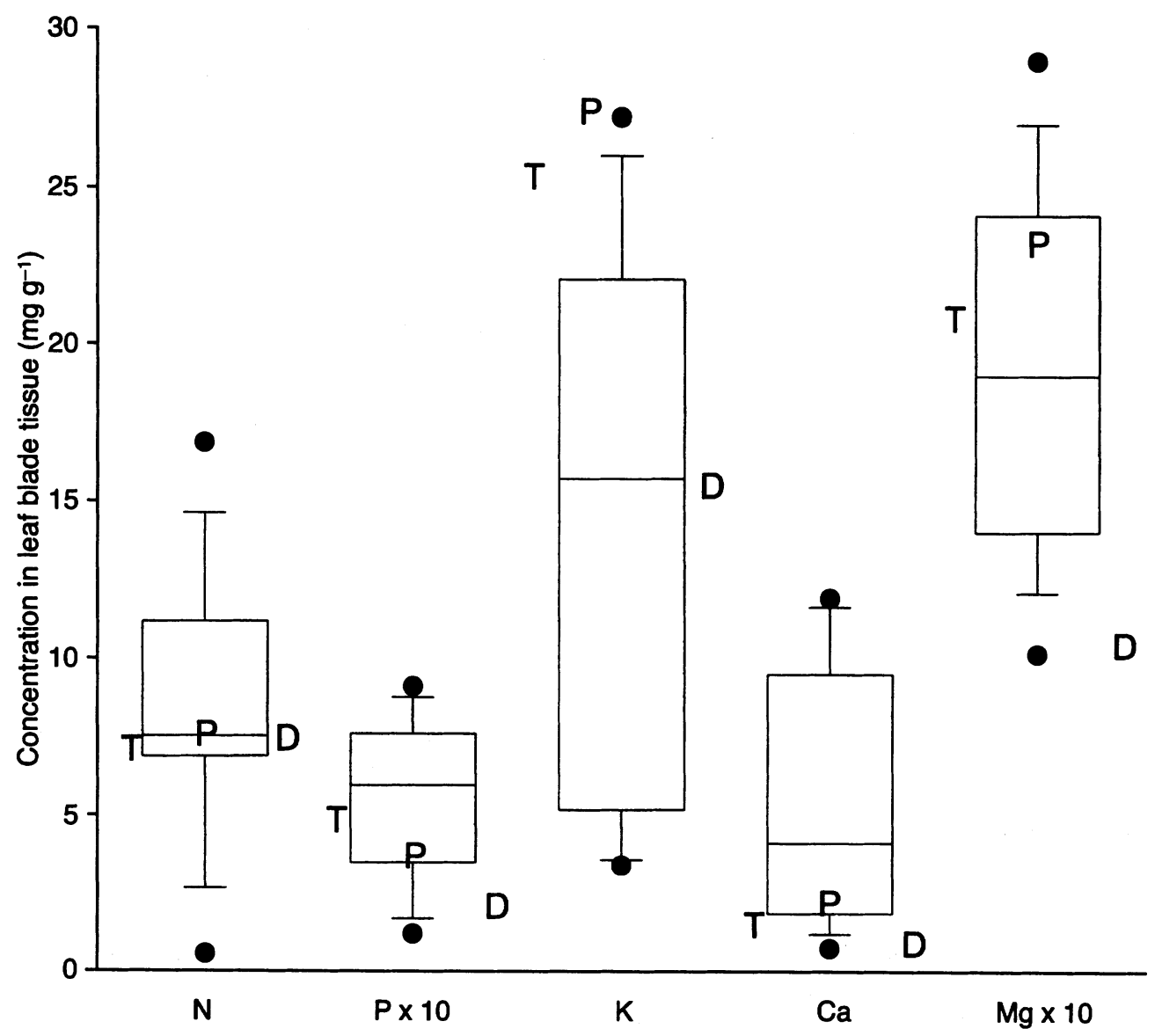

Figure 1. Box-plots of nutrient concentrations in bromeliad and epiphyte tissue in various tropical forests. Boxes have horizontal lines at the median and upper and lower quartiles. The 10 and 90 percentiles are marked by the lower and upper bars respectively. Average concentrations of Luquillo Experimental Forest samples are indicated by letters: $\mathrm{T}=$ tabonuco $(<600 \mathrm{~m}$ asl $), \mathrm{P}=$ palo colorado $(600-900 \mathrm{~m}$ asl $)$ and $\mathrm{D}=$ dwarf forest (900-1050 m asl). Data are from the current study, Benzing (1990), Hofstede et al. (1993) and Nadkarni (1984). Data from the literature beyond the 10-90 percentile range are displayed as (O).

epiphytes, including bryophytes and ferns, in other tropical forests, e.g. Colombia, Costa Rica and Jamaica (mean $=10.7 \mathrm{t} \mathrm{ha}^{-1}, \mathrm{SD}=14.1 ; \mathrm{n}=8$ ) (Hofstede et al. 1993).

In both tabonuco and palo colorado forests, debris held in bromeliad plants at the time of sampling was approximately equal to the dry weight of the bromeliad biomass, consistent with values reported for interception by epiphytic flowering plants in Costa Rica (Ingram \& Nadkarni 1993). In the dwarf forest, debris was only $26 \%$ of bromeliad biomass, reflecting lower litterfall and catchment area per plant (Table 2). Coarse litter was the largest debris component in all forest types (Table 2). Bromeliad plant tissue stores, on a forest area basis, more $\mathrm{P}, \mathrm{K}$ and $\mathrm{Mg}$, but not $\mathrm{Ca}$, than does debris impounded by plants (Table 7). Nutrients from both sources will be shed to the forest floor 
Table 6. Average concentrations of nutrients $\left(\mathrm{mg} \mathrm{l}^{-1}\right)$ in bromeliad water by forest type in the Luquillo Experimental Forest, and in rainfall and throughfall water in the tabonuco. TDN = total dissolved nitrogen; DON $=$ dissolved organic nitrogen; DOG $=$ dissolved organic carbon.

\begin{tabular}{|c|c|c|c|c|c|}
\hline & \multicolumn{3}{|c|}{ Bromeliad phytotelm water ${ }^{1}$} & \multirow{2}{*}{$\begin{array}{c}\text { Throughfall }^{2} \\
\text { Tabonuco }\end{array}$} & \multirow{2}{*}{$\begin{array}{c}\text { Rainfall }^{2} \\
\text { Tabonuco }\end{array}$} \\
\hline & Tabonuco & Palo colorado & Dwarf forest & & \\
\hline TDN & $2.98^{\mathrm{a}}$ & $0.82^{b}$ & $0.62^{b}$ & - & - \\
\hline $\mathrm{NH}_{4}-\mathrm{N}$ & $0.57^{\mathrm{a}}$ & $0.12^{\mathrm{b}}$ & $0.11^{\mathrm{b}}$ & 10.16 & 0.02 \\
\hline $\mathrm{NO}_{3}-\mathrm{N}$ & 0.028 & 0.029 & 0.022 & 0.01 & 0.03 \\
\hline DON & $2.38^{\mathrm{a}}$ & $0.67^{\mathrm{b}}$ & $0.49^{\mathrm{b}}$ & - & - \\
\hline DOC & $57.5^{\mathrm{a}}$ & $19.5^{\mathrm{b}}$ & $8.2^{\mathrm{b}}$ & 6.16 & 0.96 \\
\hline $\mathrm{PO}_{4}-\mathrm{P}$ & $0.43^{\mathrm{a}}$ & $0.18^{\mathrm{ab}}$ & $0.03^{b}$ & 0.02 & 0.01 \\
\hline $\mathrm{K}$ & 16.1 & 7.0 & 3.0 & 2.5 & 0.13 \\
\hline $\mathrm{Ca}$ & $3.75^{\mathrm{a}}$ & $3.48^{\mathrm{a}}$ & $0.57^{\mathrm{b}}$ & 1.10 & 0.37 \\
\hline $\mathrm{Mg}$ & $1.59^{\mathrm{a}}$ & $2.04^{\mathrm{a}}$ & $0.66^{\mathrm{b}}$ & 0.65 & 0.24 \\
\hline $\mathrm{Na}$ & $7.64^{\mathrm{a}}$ & $15.7^{\mathrm{b}}$ & $6.11^{\mathrm{a}}$ & 3.94 & 1.81 \\
\hline $\mathrm{Cl}$ & $22.3^{\mathrm{a}}$ & $33.9^{\mathrm{a}}$ & $9.6^{\mathrm{b}}$ & 6.86 & 3.44 \\
\hline $\mathrm{Br}$ & $0.035^{\mathrm{a}}$ & $0.061^{b}$ & $0.003^{\mathrm{c}}$ & - & - \\
\hline $\mathrm{SO}_{4}-\mathrm{S}$ & 0.88 & 1.07 & 0.75 & - & 0.99 \\
\hline
\end{tabular}

1. Values in any row with a different superscripted letter significantly different (Tukey's LSD test $n=4, P$ $<0.05$ ).

2. From McDowell (1998) and McDowell et al. (1990).

Table 7. Nutrient storage in bromeliads by compartment and forest type in the Luquillo Experimental Forest, as mass-weighted concentrations of selected nutrients in the bromeliad microcosm. Values in the table are calculated from the nutrient analyses for each component (Tables 5,6), and take account of the plant population in each forest type (Table 2). Debris values are weighted according to the relative proportion of coarse, medium and fine debris in each forest type. Note change in units between component and total values.

\begin{tabular}{llllllll}
\hline & $\mathrm{G}$ & $\mathrm{N}$ & $\mathrm{P}$ & $\mathrm{K}$ & $\mathrm{Ca}$ & $\mathrm{Mg}$ & $\mathrm{S}$ \\
\hline Tabonuco & & & & & & & \\
Animals $\left(\mathrm{g} \mathrm{ha}^{-1}\right)$ & 1.68 & 0.41 & 0.05 & 0.1 & 0.13 & 0.01 & 0.02 \\
Debris $\left(\mathrm{g} \mathrm{ha}^{-1}\right)$ & 609 & 22.9 & 0.57 & 1.86 & 11.2 & 2.03 & 7.18 \\
Plant $\left(\mathrm{g} \mathrm{ha}^{-1}\right)$ & 568 & 8.76 & 0.59 & 31.1 & 2.3 & 2.64 & 2.98 \\
Total in plant $\left(\mathrm{kg} \mathrm{ha}^{-1}\right)$ & 1.18 & 0.032 & 0.0012 & 0.033 & 0.014 & 0.0047 & 0.010 \\
Water $\left(\mathrm{g} \mathrm{ha}^{-1}\right)$ & 430 & 22.3 & 3.21 & 120 & 28.0 & 11.9 & 6.57 \\
Total $\left(\mathrm{kg} \mathrm{ha}^{-1}\right)$ & 1.61 & 0.05 & 0.004 & 0.15 & 0.04 & 0.02 & 0.02 \\
Palo colorado & & & & & & & \\
Animals $\left(\mathrm{g} \mathrm{ha}^{-1}\right)$ & 175 & 42.2 & 4.83 & 10.1 & 14.0 & 1.43 & 2.22 \\
Debris $\left(\mathrm{g} \mathrm{ha}^{-1}\right)$ & 58130 & 1742 & 30.3 & 115 & 632 & 132 & 542 \\
Plant $\left(\mathrm{g} \mathrm{ha}^{-1}\right)$ & 51430 & 829 & 39.0 & 2999 & 199 & 266 & 291 \\
Total in plant $\left(\mathrm{kg} \mathrm{ha}^{-1}\right)$ & 110 & 2.61 & 0.074 & 3.12 & 0.845 & 0.399 & 0.834 \\
Water $\left(\mathrm{g} \mathrm{ha}^{-1}\right)$ & 8100 & 341 & 74.8 & 2910 & 1446 & 847 & 444 \\
Total $\left(\mathrm{kg} \mathrm{ha}^{-1}\right)$ & 118 & 2.95 & 0.15 & 6.03 & 2.29 & 1.15 & 1.28 \\
Dwarf forest & & & & & & & \\
Animals $\left(\mathrm{g} \mathrm{ha}^{-1}\right)$ & 240 & 57.8 & 6.62 & 13.8 & 19.2 & 1.96 & 3.05 \\
Debris $\left(\mathrm{g} \mathrm{ha}^{-1}\right)$ & 75658 & 2103 & 27.9 & 146 & 623 & 236 & 650 \\
Plant $\left(\mathrm{g} \mathrm{ha}^{-1}\right)$ & 277363 & 4145 & 102 & 8563 & 393 & 553 & 1211 \\
Total in plant $\left(\mathrm{kg} \mathrm{ha}^{-1}\right)$ & 353 & 6.31 & 0.137 & 8.72 & 1.04 & 0.79 & 1.86 \\
Water $\left(\mathrm{g} \mathrm{ha}^{-1}\right)$ & 27027 & 2044 & 98.9 & 9888 & 1879 & 2175 & 2472 \\
Total (kg ha &
\end{tabular}


as outer leaves die and decay. The water reservoir held in bromeliads at the time of sampling was considerable at higher elevations, and ranged from $0.4 \mathrm{t}$ $\mathrm{ha}^{-1}$ in the palo colorado to $3.3 \mathrm{t} \mathrm{ha}^{-1}$ in the dwarf forest (Table 2). Compared with precipitation at these sites $\left(3-5 \mathrm{~m} \mathrm{y}^{-1}\right)$, the amount of water stored in phytotelmata is insignificant (e.g. an amount equal to $0.5 \mathrm{~mm}$ precipitation was stored in phytotelmata at the dwarf forest site at the time of sampling). Storage $\left(\mathrm{kg} \mathrm{ha}^{-1}\right)$ of $\mathrm{K}, \mathrm{Ca}$ and $\mathrm{Mg}$ in phytotelm water was similar to or greater than that stored in bromeliads, their debris and animals in all forests (Table 7). The relative amounts of $P$ in the phytotelm water, compared with the total in the plant, declined from three fold in the tabonuco to 0.75-fold in the dwarf forest (Table 7). The phytotelm water had lower storage of $\mathrm{C}$ and $\mathrm{N}$ than bromeliads in all forest types. In general, the proportion of nutrients stored in phytotelmata was greater in the tabonuco than in the other two forests.

Invertebrate tissue contained higher concentrations of all elements, except carbon, than plant tissue or debris (Table 5) but, because animal biomass was proportionally low, their contribution to total nutrient storage was small (Table 7). The ratio of animal biomass to plant debris was similar for all forests but increased with elevation (Table 4). It was not possible to calculate animal productivity on an annual basis, as generation times of members of the communities are not known.

\section{Comparison with other compartments in Luquillo Experimental Forest}

Compared with other compartments within the Luquillo Experimental Forest, the storage of either biomass or nutrients in the bromeliad system is not exceptionally large. In the dwarf forest, with the highest bromeliad density (with a projected ground cover of $25 \%$ ) the standing stock of debris represents $<4 \%$ of the forest floor standing stock (Table 8). More nutrients are, therefore, stored in litter and soil fungi in the top $10 \mathrm{~cm}$ of tabonuco forest soil than in bromeliads in any of the three forest types (Lodge 1996). Nutrient storage in bromeliads and their contents in the dwarf forest is approximately equivalent to the biomass $\left(0.6 \mathrm{t} \mathrm{ha}^{-1}\right)$ and storage in the understorey (saplings, herbs and ferns) in the tabonuco forest (Scatena et al. 1993).

Table 8. Forest productivity and litterfall, and the relative importance of bromeliads as impounders of litter in three forest types in the Luquillo Experimental Forest.

\begin{tabular}{|c|c|c|c|}
\hline & \multicolumn{3}{|c|}{ Forest type } \\
\hline & Tabonuco & Palo colorado & Dwarf forest \\
\hline Total aboveground NPP $\left(\mathrm{t} \mathrm{ha}^{-1} \mathrm{y}^{-1}\right)^{1}$ & 10.5 & 7.6 & 3.7 \\
\hline Tree litterfall $\left(\mathrm{t} \mathrm{ha}^{-1} \mathrm{y}^{-1}\right)^{1}$ & 8.6 & 6.8 & 3.1 \\
\hline Total bromeliad litter/yearly tree litterfall (\%) & 0.015 & 1.79 & 4.71 \\
\hline Forest floor standing litter $\left(\mathrm{t} \mathrm{ha}^{-1}\right)^{2}$ & 6.0 & 8.76 & 4.34 \\
\hline Bromeliad debris $\left(\mathrm{g} \mathrm{m}^{-2} \text { bromeliad }\right)^{3}$ & 57.6 & 68.9 & 57.5 \\
\hline$\%$ of litter stock held by bromeliads & 0.02 & 1.4 & 3.4 \\
\hline
\end{tabular}




\section{Nutrient budgets}

Nutrient budgets for these microcosms indicate the annual nutrient flow of $\mathrm{N}, \mathrm{P}, \mathrm{K}, \mathrm{Ca}$ and $\mathrm{Mg}$ through bromeliads is considerably greater than the annual accumulation within the microcosm (Table 9). Moreover, both tabonuco and palo colorado forest bromeliads accumulate less than $5 \%$ of the nutrients that pass through them on an annual basis. While dwarf forest bromeliad microcosms also accumulate less than $5 \%$ of the annual inputs of $\mathrm{Ca}$ and $\mathrm{Mg}$, they accumulate about $25 \%$ of $\mathrm{P}$ and $\mathrm{K}$ inputs.

Nutrients that accumulate in debris are a small fraction of the total nutrients in litterfall intercepted by bromeliads (Table 9). Annual nutrient inputs to palo colorado and dwarf forest microcosms from throughfall exceed that from litter, except for $\mathrm{N}$, and $\mathrm{P}$ in the palo colorado. Likewise, the accumulation of nutrients, except $\mathrm{Ca}$, in bromeliad tissue is typically greater than the accumulation in debris.

\section{Overall changes with forest type}

Simpson's diversity index, which takes abundance into account, and Margalef's index of species richness were plotted against $\mathrm{C} / \mathrm{N}$ ratios of debris in the microcosms (Figure 2). Abundance and species richness exhibit different trends with changing $\mathrm{C} / \mathrm{N}$, with the Simpson indices having a linear relationship with rate of turnover, and the Margalef species richness showing a unimodal pattern, highest in the palo colorado forest (Table 10). The divergence between species richness and animal abundance seen in the intermediate palo colorado forest indicates that these parameters are independent of each other. Annual nutrient inputs per plant of $\mathrm{Mg}, \mathrm{Ca}, \mathrm{K}$ and $\mathrm{P}$ (Table 10) were low in dwarf forest plants and higher in tabonuco and palo colorado plants, which had similar values. The slightly higher values in the palo colorado plants reflects their larger size. Trends in nutrient concentrations, animal and bromeliad productivity and biomass, and species richness are summarized in Figure 3.

\section{DISGUSSION}

Nutrient cycling through the bromeliad microcosm

Bromeliad microcosms have a high throughput of low concentration nutrients. These are not nutrient-limited systems, however, and their relative importance as storage compartments increases with elevation as the forest canopy becomes more open and bromeliad density increases. Only in the dwarf forest are bromeliads sufficiently abundant to be significant in the litter nutrient cycle of the forest ecosystem and NPP.

Tabonuco bromeliads contain the highest nutrient concentrations, perhaps because of richer debris, less dilution and leaching due to lower rainfall, and more consecutive dry days. Despite the lower concentration of many nutrients, palo colorado plants have the largest biomass and form large complexes, by sympodial branching after flowering. In the low-nutrient environment of the 
Table 9. Preliminary budgets $\left(\mathrm{g} \mathrm{ha}^{-1} \mathrm{y}^{-1}\right)$ for selected nutrients by forest type for bromeliads in the Luquillo Experimental Forest.

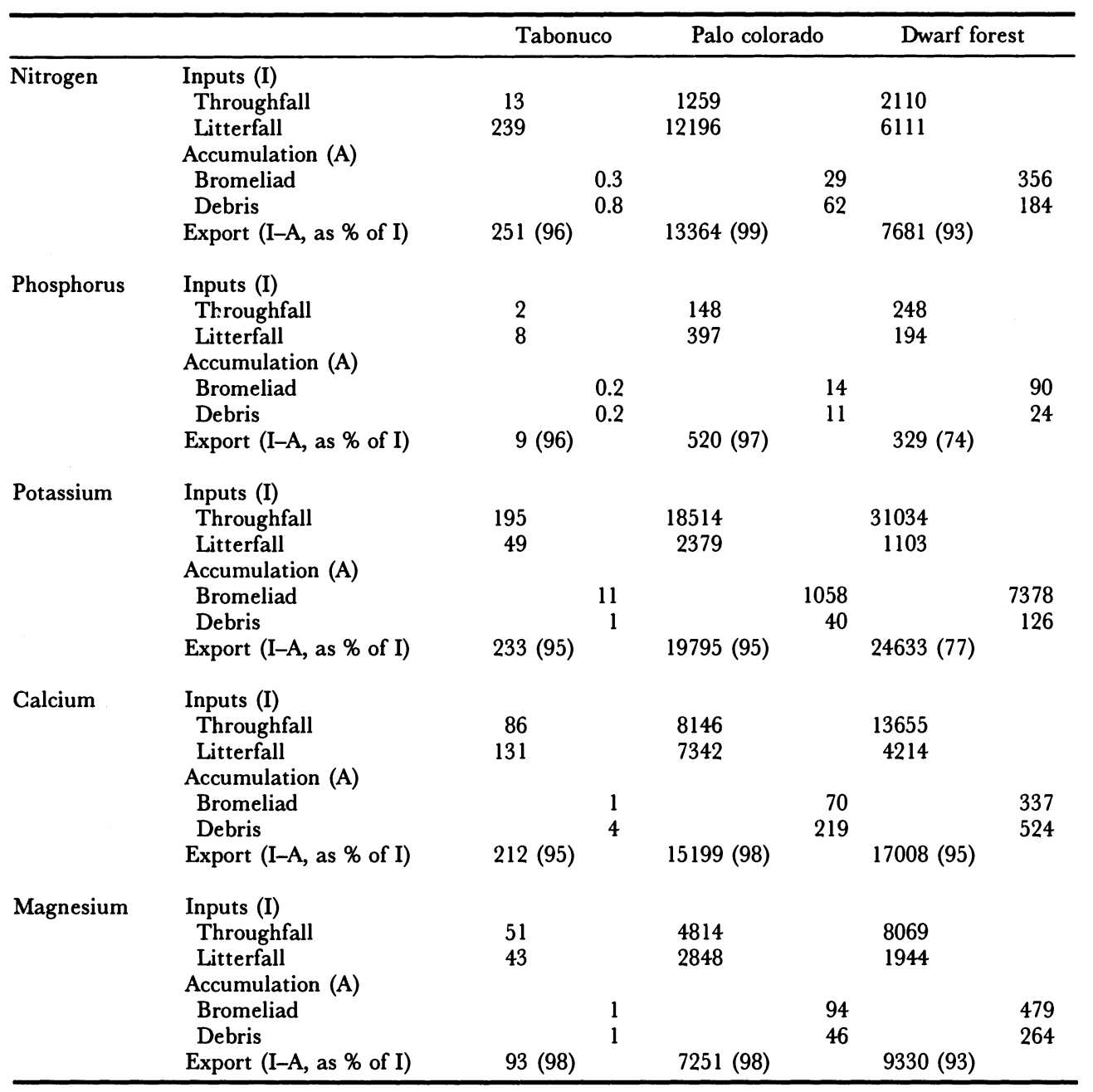

dwarf forest such complexes do not form, and they are infrequent and less complex in the tabonuco. The bromeliads studied were all C3 plants, requiring humid environments but intolerant of deep shade (Smith et al. 1986). During the dry season the tabonuco forest can suffer severe drought, with consequent checks to bromeliad growth. This is less likely to happen in the palo colorado, which may explain more axillary growth, longer leaves and greater biomass, even though plants were mainly the same species (G. berteroniana).

The growth and reproductive strategy of dwarf forest bromeliads (mainly $V$. sintenisii) differs from that of plants in the two lower forests. The former are exposed to fluctuations in insolation because of rapidly changing cloud cover and sparse canopy. Though protected to some extent by red screening pigments 

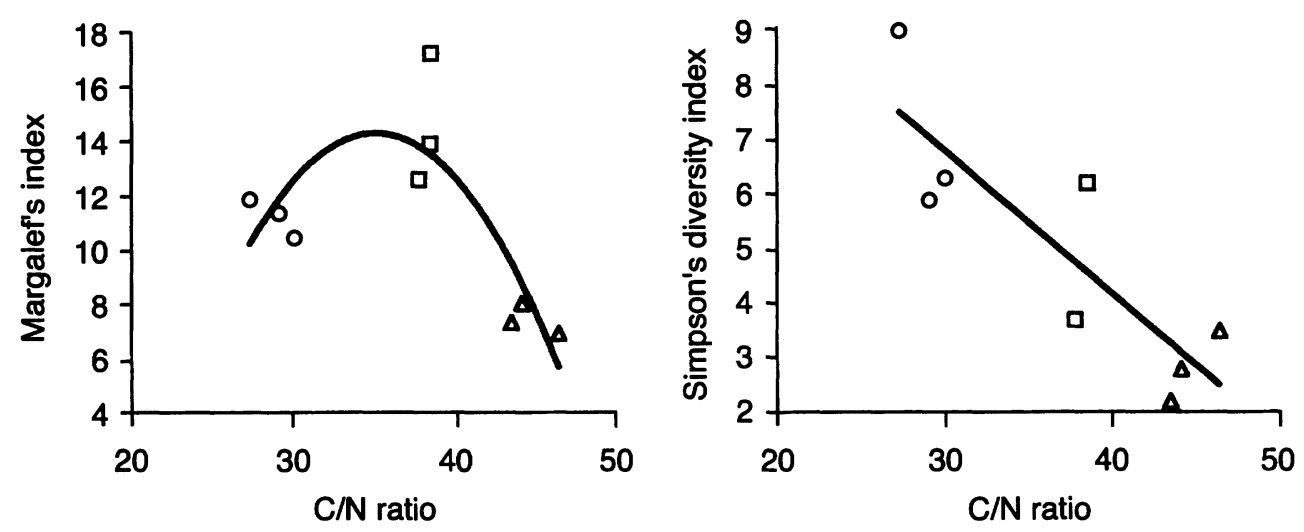

Figure 2. Relationship between Margalef's and Simpson's indices and $\mathrm{C} / \mathrm{N}$ ratios $\left(\mathrm{r}^{2}=0.663\right.$ and 0.732 , respectively) in three forest types in the Luquillo Experimental Forest: Tabonuco (O), palo colorado ( $\square$ ) and dwarf forest $(\triangle)$.

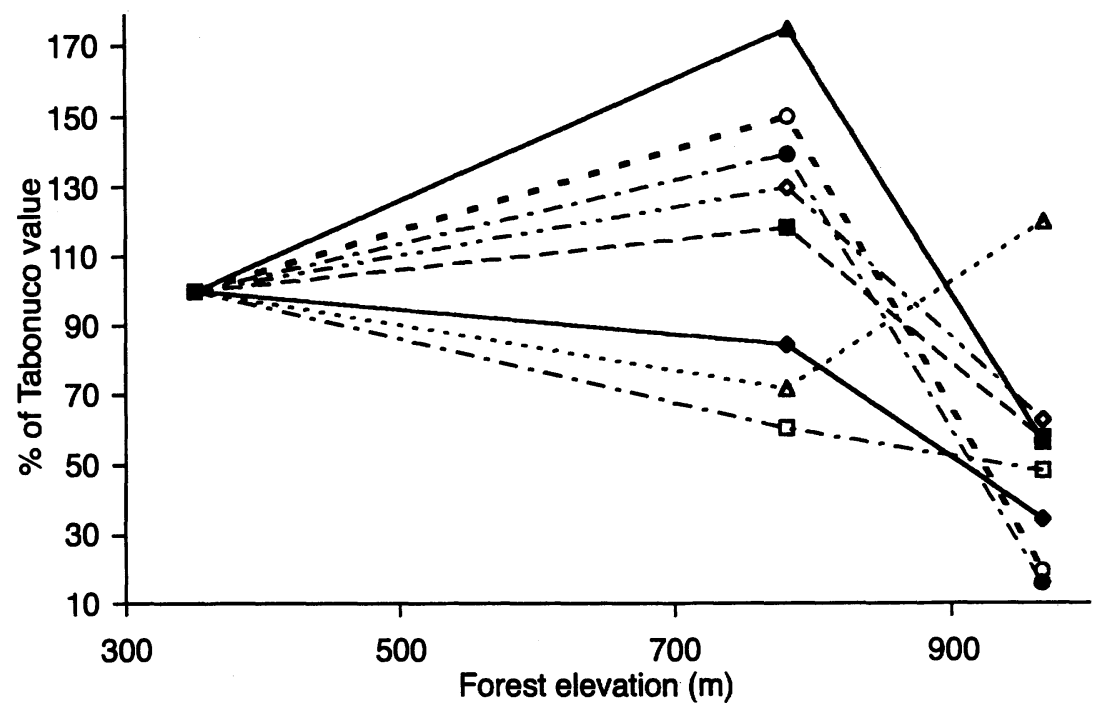

Figure 3. Diagram showing trends with elevation of biological and nutritional parameters in three forest types in the Luquillo Experimental Forest (tabonuco $=100 \%$ ). Mean animal dry weight $(\mathbf{\Delta})$; total animal biomass/plant (O); bromeliad debris/plant $(\Theta)$; bromeliad biomass $(\diamond)$; species richness $(\square)$; animal abundance $(\diamond) ; \mathrm{Fe}, \mathrm{Al}$ and $\mathrm{Mg}(\triangle) ; \mathrm{P}, \mathrm{K}, \mathrm{Ca}$ and $\mathrm{Mn}(\square)$. The data for minerals relate to their concentrations in debris in bromeliad rosettes. Elevational ranges: tabonuco, $<600 \mathrm{~m}$ asl; palo colorado, $600-900 \mathrm{~m}$ asl; dwarf forest, 900-1050 $\mathrm{m}$ asl.

(Benzing 1980), their rapid leaf turnover and, therefore, renewal of photosynthetic tissue, appears to be an adaptation to the destruction of photosynthetic pigments by light. Rapid vegetative growth presumably occurs at the expense of flower and seed production, signs of which were absent from the study plants and only occasionally observed in the population. Because of low nutrient levels in their phytotelmata, high insolation, and small size, dwarf forest bromeliads may be assumed to be plants under stress. Because of their physiological 
Table 10. Nutrient inputs to bromeliad microcosms (g per plant $\left.\mathrm{y}^{-1}\right),{ }^{1} \mathrm{C} / \mathrm{N}$ ratios of debris, and animal diversity indices in three forest types in the Luquillo Experimental Forest.

\begin{tabular}{lccc}
\hline & \multicolumn{3}{c}{ Forest type } \\
\cline { 2 - 4 } & Tabonuco & Palo colorado & Dwarf forest \\
\hline Nutrients & & & \\
$\mathbf{P}$ & 0.22 & 0.18 & 0.01 \\
$\mathbf{K}$ & 5.42 & 6.74 & 1.00 \\
$\mathbf{C a}$ & 4.82 & 5.00 & 0.56 \\
$\mathbf{M g}$ & 2.09 & 2.47 & 0.31 \\
C/N ratio & & & \\
1993/94 & 29.1 & 37.7 & 44.0 \\
1994/95 & 27.3 & 38.5 & 43.4 \\
1996 & 30.0 & 38.4 & 46.3 \\
Simpson's diversity index & & & \\
1993/94 & 5.9 & 3.7 & 2.8 \\
1994/95 & 9.0 & 6.2 & 2.2 \\
1996 & 6.3 & $\mathbf{n . a}{ }^{2}$ & 3.5 \\
Margalef's species richness & & & \\
1993/94 & 11.4 & 12.6 & 7.1 \\
1994/95 & 11.9 & 17.2 & 7.0 \\
1996 & 10.5 & 13.9 & \\
\hline
\end{tabular}

1. Throughfall + litter values (Table 9)/plant density (Table 2).

2. Comparable estimate not available, because only 10 plants were sampled.

adaptations, however, and the high humidity and throughput of water, they are in fact the most successful bromeliads, in terms of total biomass and abundance, at any elevation.

Differences in bromeliad leaf turnover rate have implications for the time scale for the return of impounded nutrients to the forest floor and developmental time for invertebrates. The dwarf forest has the highest turnover of nutrients through the bromeliad microcosm, but the shortest time for life cycles to be completed.

\section{Nutrient effects on phytotelm animal communities}

Animal biomass follows the same pattern as bromeliad biomass, peaking at mid-elevation. (Figure 3). The ratio of invertebrate abundance to its biomass also shows that individuals are larger in the palo colorado (Table 4). The common explanation for larger size of both plants and animals may be that the mid-elevational forest provides the most stable environment, in terms of humidity, rainfall and temperature, so that periods of reduced growth are decreased. Small early instars and young plants would be more vulnerable to desiccation during the longer dry periods characteristic of the tabonuco forest. Palo colorado microcosms support a high abundance of relatively large predators (Arachnida, Chilopoda and predatory Coleoptera larvae). Except for a few spiders, large predators are absent from the dwarf forest, consistent with the low number of prey items to support them (Richardson 1999). There have been few studies of biomass and body size along elevational gradients. Some animals, such as terrestrial molluscs, show a reduction in size with increasing elevation, attributed to a reduction in growth rates in cooler environments 
(Begon et al. 1996). For five species of mollusc in the Luquillo Experimental Forest, however, one exhibited no change with increasing elevation, one decreased in size, and three others were larger (Alvarez 1997). The latter species, are algal feeders and higher rainfall and humidity may reduce the risk of desiccation, thus increasing the time available for foraging. Three frog species (Eleutherodactylus spp.) also increase in size with increasing elevation in the Luquillo Mountains up to $750 \mathrm{~m}$ asl (Stewart \& Woolbright 1996), most notably the coqui (E. coqui Thomas). Their population density, however, decreases from $45000 \mathrm{ha}^{-1}$ at $30 \mathrm{~m}$ to $2500 \mathrm{ha}^{-1}$ at $750 \mathrm{~m}$ elevation. Populations, especially those of juveniles, also drop significantly due to high mortality after long periods without rain, as they are dependent on moist retreat sites in the forest floor litter.

Adaptation to increasing elevation appears, therefore, to be species-based, with a complex of factors-humidity, temperature, rainfall and food supplydetermining growth rates and body size. Palo colorado and dwarf forests are more amenable habitats for species most vulnerable to desiccation. In the spatially restricted dwarf forest bromeliad microhabitat, however, the quality and quantity of the nutrient base becomes the limiting factor, so both animal abundance and body size are reduced. These observations support those of Cotgreave et al. (1993), who found that there was no evidence of a negative relationship between animal abundance and body size of morphospecies in bromeliad microcosms.

Animal biomass is small relative to bromeliad debris stocks $(<0.5 \%$ in all forests), but with the proportion increasing with elevation. Low animal biomass is to be expected from a detrital food source which is physically difficult to break down and digest, because of its high lignin content. The same problem is faced by stream invertebrates living on detritus washed in from the canopy (Merritt et al. 1984).

For the common cations, animal species richness increases as nutrient inputs per plant increase, such that diversity and inputs are significantly larger in the tabonuco and palo colorado forests than in the dwarf forest. Nutrient inputs into individual plants in the palo colorado are slightly higher than in the tabonuco (Table 10), because of larger plant size. We do not suggest, however, that these small differences are biologically significant and explain the consistently higher species richness in the palo colorado bromeliads. Although there are differences in nutrient abundance between forests, the large amounts passing through these microcosms relative to uptake, particularly in the lower two forests, suggests that relationships with animal communities are not solely related to nutrient limitations or allocations. We suggest, instead, that the structure of animal communities reflects the spatial environment of the microcosm, and the wider forest ecosystem in which they exist.

It is evident that abundance and species richness are independent variables, and forest-wide species richness is unrelated to the total area of habitat available for colonization. Rosenzweig (1995) considered habitat area to be the 
factor which most influences species richness, with larger areas supporting more species because of low extinction rates. The dwarf forest, with the highest density of bromeliads, has the lowest species richness, and the large patches of bromeliads found there do not operate functionally as large islands. The dwarf forest, occupying only mountain peaks, is the smallest area of the Luquillo Experimental Forest (Brown et al. 1983), and as individual bromeliads behave as islands (Richardson 1999) then the smallest islands are the bromeliads of the dwarf forest. The decline in animal abundance mirrors the decline in nutrient inputs and decreasing decay rates $(\mathrm{C} / \mathrm{N}$ ratios) along the forest elevational gradient. Abundance may also be related to spatial factors within the bromeliad microcosm, i.e. the number of leaf pools per plant available for colonization, which declines with elevation. Species richness is not related to nutrients in the forest ecosystem per se, and is highest in the palo colorado, where major cation concentrations are significantly lower than in the tabonuco. This intermediate forest would appear to be the most favourable habitat for invertebrate survival, having lower wind velocities than the dwarf forest and higher rainfall than the tabonuco (Weaver 1994), and an intermediate level of anoxia in phytotelmata. Palo colorado bromeliads are less likely to dry out and species with lower abundance are less likely to suffer extinction. Selection favours small bromeliads in the dwarf forest because supporting branches are smaller, litter production is lower and wind velocities are higher. Consequently dwarf forest bromeliads contain a low nutrient base, and greater competition for nutrients is indicated by the high invertebrate community dominance index (Richardson 1999).

Relationships between animal abundance, species richness, nutrient inputs and environmental conditions are too complex to justify assumptions of simple relationships between nutrient resources and diversity, even in apparently simple microhabitats. In addition to nutrients, animals require shelter from a changing environment and refuges from predators and parasites, and so have specific habitat requirements. The greater the structural heterogeneity and plant species richness of the overall forest environment, the greater the resource provision to support a higher animal species richness (Lawton 1986, MacArthur \& MacArthur 1961, Uetz 1991). The palo colorado forest is the most heterogeneous of the three studied. It has the highest density of vines and epiphytes, soils are covered by a thick surface network of roots with bryophytes, and herbaceous ground cover is greater than in the tabonuco forest (Weaver 1994).

The bromeliad habitat provides stable long-term conditions in which many generations of invertebrates can breed. Species that breed there, but leave as adults to pass into the general forest ecosystem (e.g. larval Diptera and beetles, and cockroach nymphs), made up $c .80 \%$ of the total collection. If all survived to adulthood this would represent 144 (tabonuco), 98 (palo colorado) and 51 (dwarf forest) food items per plant passing into the food chain. Taking into 
account the increasing bromeliad density with elevation (Table 2), the values here represent $c .6 .5 \times 10^{3}, 0.24-0.93 \times 10^{6}$ and $0.9-5.6 \times 10^{6}$ potentially emigrant food items ha ${ }^{-1}$ respectively at the time of sampling. Because bromeliads are long-lived, and can support many successive generations of invertebrate aninals, their contribution to palo colorado and dwarf forest food chains could be considerable. They will be less important in the tabonuco, where bromeliad densities are very low.

Many bromeliad residents are highly specialized morphologically to live within a spatially restricted habitat, endemic to these plants and to Puerto Rico (Hansen \& Richardson 1998, Richardson 1999). Even species which only spend the larval stage of their life cycle in phytotelmata are largely restricted to bromeliads, as bodies of still water are not available elsewhere in steep montane forest, and other phytotelmata (e.g. in fallen leaves, palm floral bracts and frond bases) are too ephemeral to support the same species. The bromeliad microcosm is, therefore, a unique habitat contributing to forest diversity and food chains.

\section{ACKNOWLEDGEMENTS}

This research was conducted as part of the Long-Term Ecological Research Program in the Luquillo Experimental Forest, with additional funds provided by the USDA Forest Service, Napier University, and The Carnegie Trust for the Universities of Scotland. Special thanks to the staff of the El Verde Field Station of the University of Puerto Rico and the plant analysis laboratory of the International Institute of Tropical Forestry. We are grateful to Robin Henderson for statistical advice, to Rebecca Ostertag and Ernesto Medina for valuable comments, and to two anonymous referees for helpful reviews of the paper.

\section{LITERATURE GITED}

ALVAREZ, J. 1997. Patterns of abundance, species richness, habitat use, and morphology in tropical terrestrial molluscs. Doctoral Dissertation. Texas Tech. University, Lubbock, Texas.

ASBURY, C. H., MCDOWELL, W.H., TRINIDAD-PIZARRO, R. \& BERRIOS, S. 1994. Solute deposition from cloud water to the canopy of a Puerto Rican montane forest. Atmospheric Environment 28:17731780.

BEGON, M., HARPER, J. L. \& TOWNSEND, C. R. 1996. Ecology of individuals, populations and communities. (3rd edition.) Blackwell Science, Oxford. $1068 \mathrm{pp}$.

BENZING, D. H. 1980. The biology of bromeliads. Mad River Press, Eureka, CA. 305 pp.

BENZING, D. H. 1990. Vascular epiphytes. Cambridge University Press, Cambridge. 354 pp.

BROWN, J. H. \& GIBSON, A. C. 1983. Biogeography. Mosby, St Louis, MO. 643 pp.

BROWN, S., LUGO, A. E., SILANDER, S. \& LIEGEL, L. 1983. Research history and opportunities in the Luquillo Experimental Forest. U.S. Forest Service General Technical Report No. SO-44, Southern Forest Experiment Station, New Orleans, Louisiana. $128 \mathrm{pp}$.

COTGREAVE, P., HILL, M. J. \& MIDDLETON, D. A. J. 1993. The relationship between body size and population size in bromeliad tank faunas. Biological Journal of the Linnean Society 49:367-380.

FRANK, J. H. 1983. Bromeliad phytotelmata and their biota, especially mosquitoes. Pp. 101-128 in Frank, J. H. \& Lounibos, L. P. (eds). Phytotelmata: terrestrial plants as hosts for aquatic insect communities. Plexus Publishing Inc., New Jersey.

GARCÍA-MARTINÓ, A. R., WARNER, G. S., SCATENA, F. N. \& GIVCO, D. L. 1996. Rainfall, runoff 
and elevation relationships in the Luquillo Mountains of Puerto Rico. Caribbean Journal of Science 32:413-424.

GROEBNER, D. F. \& SHANNON, P. W. 1981. Business statistics, a decision-making approach. 2nd edn. Merrill Publishing Co., Columbus, Ohio. 848 pp.

HANSEN, M. \& RICHARDSON, B. A. 1998. A new species of Omicrus Sharp (Coleoptera: Hydrophilidae) from Puerto Rico and its larva, the first known larva of Omicrini. Systematic Entomology 23:1-8.

HOFSTEDE, R. G. M., WOLF, J. H. D. \& BENZING, D. H. 1993. Epiphytic biomass and nutrient status of a Colombian Upper Montane Rain Forest. Selbyana 14:37-45.

HURLBERT, S.H. 1984. Pseudoreplication and the design of ecological field experiments. Ecological Monographs 54:187-211.

INGRAM, S. W \& NADKARNI, N.M. 1993. Composition and distribution of epiphytic organic matter in a neotropical cloud forest, Costa Rica. Biotropica 25:370-383.

LAESSLE, A. M. 1961. A micro-limnological study of Jamaican bromeliads. Ecology 42:499-517.

LAWTON, J. H. 1986. Surface availability and insect community structure: the effects of architecture and fractal dimension of plants. Pp. 317-331 in Juniper, B. E. \& Southwood, T. R. E. (eds). Insects and the plant surface. Edward Arnold, London.

LEME, E. M. C.\& MARIGO, L.C. 1993. Bromeliads in the Brazilian wilderness. Marigo Comunição Visual, Rio de Janeiro. 183 pp.

LODGE, D. J. 1996. Microorganisms. Pp. 53-108 in Reagan, D. P. \& Waide, R. B. (eds). The food web of a tropical rain forest. University of Chicago Press, Chicago.

LODGE, D. J., SCATENA, F. N., ASBURY, C. E. \& SÁNCHEZ, M. J. 1991. Fine litterfall and related nutrient inputs resulting from Hurricane Hugo in subtropical wet and lower montane rain forest of Puerto Rico. Biotropica 23:336-342.

LUH HUANG, C.Y. \& SCHULTE, E. E. 1985. Digestion of plant tissue for analysis by ICP emission spectroscopy. Communications in Soil Science and Plant Analysis 16:943-958.

MACARTHUR, R. H. \& MACARTHUR, J. W. 1961. Bird species diversity. Ecology 42:592-598.

MAGUIRE, B., Jr. 1970. Aquatic communities in bromeliad leaf axils and the influence of radiation. Pp. E-95-E-101 in Odum, H. T. \& Pigeon, R. F. (eds). A tropical rain forest: a study of irradiation and ecology at El Verde, Puerto Rico. TID-24270. Division of Technical Information, U.S. Atomic Energy Agency, Washington, DC.

MCDOWELL, W. H. 1998. Internal nutrient fluxes in a Puerto Rican rain forest. Journal of Tropical Ecology 14:521-536.

MCDOWELL, W. H., GINEZ-SÁNCHEZ, C., ASBURY, C. E. \& RAMOS PEREZ, G. R. 1990. Influence of sea salt aerosols and long range transport on precipitation chemistry at El Verde, Puerto Rico. Atmospheric Environment 24A:2813-2821.

MEDINA, E., CUEVAS, E. \& WEAVER, P. 1981. Composición foliar y transpiración de especies leñosas de Pico del Este, Sierra de Luquillo, Puerto Rico. Acta Cientifica Venezuelana 32:159-165.

MERRIAM, J., MCDOWELL, W. H. \& CURRIE, W. S. 1996. A high-temperature catalytic oxidation technique for determining total dissolved nitrogen. Soil Science Society of America Journal 60:1050-1055.

MERRITT, R.W., CUMMINS, K. W. \& BURTON, T. M. 1984. The role of aquatic insects in the processing and cycling of nutrients. Pp. 134-163 in Resh, V. H. \& Rosenberg, D. M. (eds). The ecology of aquatic insects. Praeger, New York.

NADKARNI, N.M. 1984. Epiphyte biomass and nutrient capital of a neotropical elfin forest. Biotropica $16: 249-256$.

NADKARNI, N. M. \& MATELSON, T. J. 1992. Biomass and nutrient dynamics of epiphytic litterfall in a neotropical montane forest, Costa Rica. Biotropica 24:24-30.

NADKARNI, N. M. \& PRIMACK, R. B. 1989. The use of gamma spectrometry to measure within-plant nutrient allocation of a tank bromeliad, Guzmania lingulata. Selbyana 11:22-25.

PICADO, M. C. 1913. Les broméliacées épiphytes considérées comme milieu biologique. Thèses, Faculté des Sciences de Paris.

RAHBEK, C. 1995. The elevational gradient of species richness: a uniform pattern? Ecography 18:200205.

RAHBEK, C. 1997. The relationship among area, elevation, and regional species richness in neotropical birds. American Naturalist 149:875-902.

RICHARDSON, B. A. 1999. The bromeliad microcosm and the assessment of faunal diversity in a neotropical forest. Biotropica 31:321-336.

ROSENZWEIG, M. L. 1995. Species diversity in space and time. Cambridge University Press, Cambridge. $436 \mathrm{pp}$.

SÁNCHEZ, M. J., LÓPEZ, E. \& LUGO, A. E. 1997. Chemical and physical analyses of selected plants and soils from Puerto Rico (1981-1990). Research Note IITF-RN-1. US Department of Agriculture, Forest Service, International Institute of Tropical Forestry, Rio Piedras, Puerto Rico. 112 pp.

SCATENA, F. N., SILVER, W., SICCAMA, T., JOHNSON A. \& SÁNCHEZ, M.J. 1993. Biomass and 
nutrient content of the Bisley Experimental Watersheds, Luquillo Experimental Forest, Puerto Rico, before and after Hurricane Hugo, 1989. Biotropica 25:15-27.

SILVER, W. L. 1992. The effects of small-scale catastrophic disturbances in carbon and nutrient cycling in a lower montane subtropical wet forest in Puerto Rico. PhD Thesis, Yale University School of Forestry and Environmental Science.

SMITH, J. A. C., GRIFFITHS, H. \& LÜTTGE, U. 1986. Comparative ecophysiology of CAM and C3 bromeliads. 1. The ecology of the Bromeliaceae in Trinidad. Plant, Cell and Environment 9:359-376.

SOKAL, R. R. \& ROHLF, F. J. 1973. Introduction to biostatistics. Freeman and Co., San Francisco, California. 368 pp.

STEWART, M. M. \& WOOLBRIGHT, L. L. 1996. Amphibians. Pp. 273-320 in Regan, D. P. \& Waide, R. B. (eds). The food web of a tropical rain forest. University of Chicago Press, Chicago.

TABATABAI, M. A. \& BREMMER, J. M. 1991. Automated instruments for determination of total Carbon, Nitrogen and Sulphur in soils by combustion techniques. Pp. 261-286 in Soil analysis, modern instrument techniques (2nd edition). Marcel Dekker Inc., New York.

UETZ, G. W. 1991. Habitat structure and spider foraging. Pp. 325-348 in Bell, S. S., McCoy, E. D. \& Mushinsky, H. R. (eds). Habitat structure. The physical arrangement of objects in space. Chapman \& Hall, London.

VITOUSEK, P. M. \& SANFORD, R.L. 1986. Nutrient cycling in moist tropical forests. Annual Review of Ecology and Systematics 17:137-167.

WEAVER, P. L. 1994. Baño de Oro Natural Area Luquillo Mountains, Puerto Rico. General Technical Report SO-111. USDA Forest Service, Southern Forest Experiment Station, New Orleans, LA. 55 pp.

WEAVER, P. L. \& MURPHY, P. G. 1990. Forest structure and productivity in Puerto Rico's Luquillo Mountains. Biotropica 22:69-82. 